


\section{THE MARK TWAIN LIBRARY}

The Library offers for the first time popular editions of Mark Twain's best works just as he wanted them to be read. These moderately priced volumes, faithfully reproduced from the California scholarly editions and printed on acid-free paper, are expertly annotated and include all the original illustrations that Mark Twain commissioned and enjoyed.

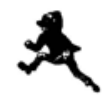

"Huck waited for no particulars. He sprang away and sped down the hill as fast as his legs could carry him." 
Contributing Editors for This Volume Richard Bucci

Victor Fischer

Michael B. Frank

Kenneth M. Sanderson 

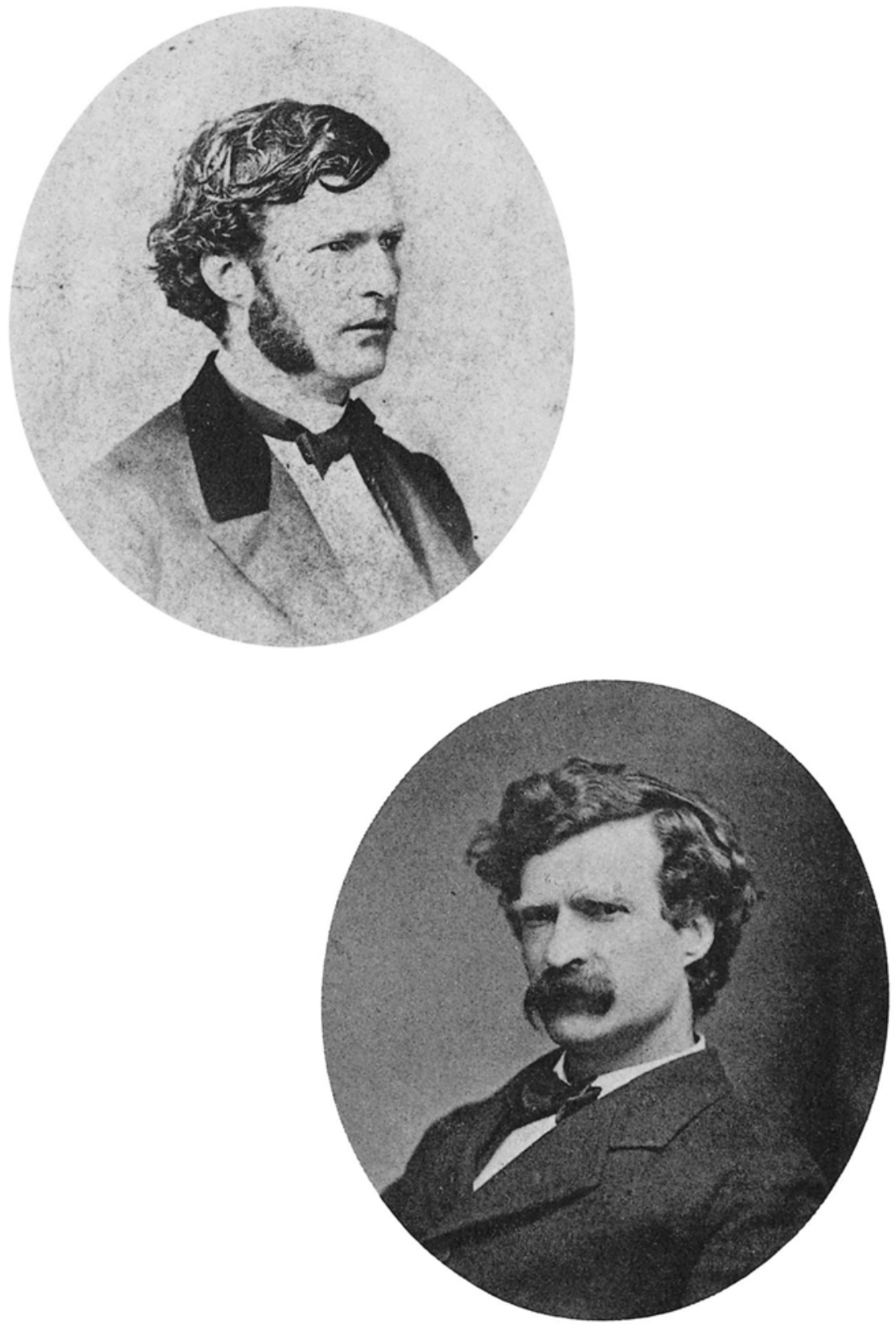

Samuel L. Clemens in 1863 (above) and 1872. Mark Twain Papers, The Bancroft Library (CU-MARK). 


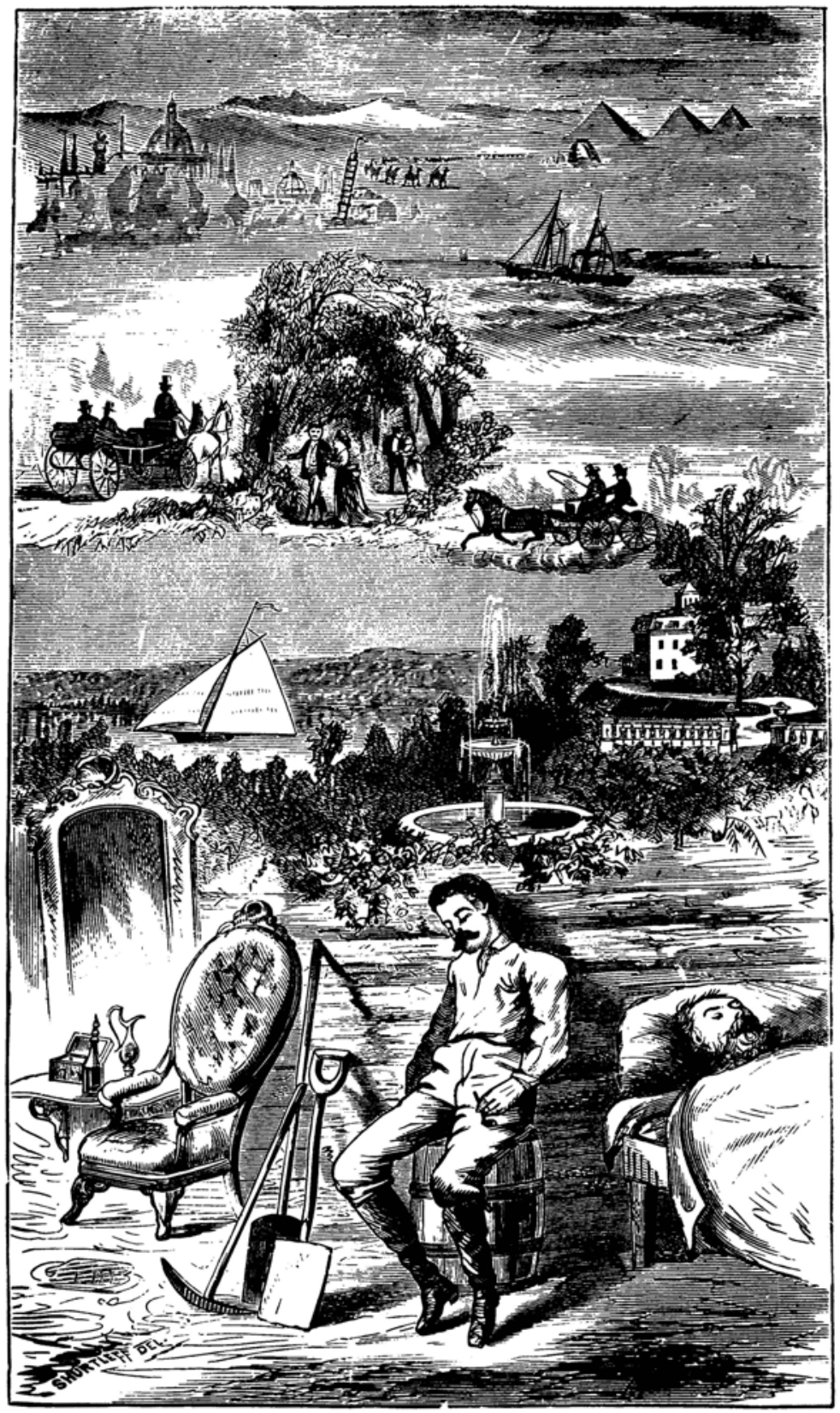

The Miner's Dream. 


\section{MARK TWAIN}

\section{ROUGHING IT}

ILLUSTRATED BY TRUE WILLIAMS, EDWARD F. MULLEN, AND OTHERS

Editors

Harriet Elinor Smith and Edgar Marquess Branch

Associate Editors

Lin Salamo and Robert Pack Browning

A publication of the

Mark Twain Project of The Bancroft Library

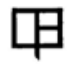

University of California Press

Berkeley

Los Angeles

London 


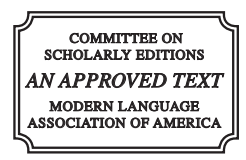

The text of this Mark Twain Library edition of Roughing It is identical with the text of the scholarly edition of Roughing It, edited by Harriet Elinor Smith and Edgar Marquess Branch (University of California Press, 1993). It was established in accord with the standards of the Center for Scholarly Editions (CSE). Editorial work was supported by a generous grant from the L. J. Skaggs and Mary C. Skaggs Foundation and by matching funds from the National Endowment for the Humanities, an independent federal agency.

University of California Press, one of the most distinguished university presses in the United States, enriches lives around the world by advancing scholarship in the humanities, social sciences, and natural sciences. Its activities are supported by the UC Press Foundation and by philanthropic contributions from individuals and institutions. For more information, visit www.ucpress.edu.

University of California Press Berkeley and Los Angeles, California

University of California Press, Ltd. London, England

The edited text of Roughing It, notes, and maps are (C) 1993 by The Regents of the University of California. Editorial foreword and note on the text are (C) 1995 by The Regents of the University of California.

Manufactured in the United States of America.

$\begin{array}{llllllllll}19 & 18 & 17 & 16 & 15 & 14 & 13 & 12 & 11 & 10\end{array}$

$\begin{array}{llllllllll}10 & 9 & 8 & 7 & 6 & 5 & 4 & 3 & 2 & 1\end{array}$
Library of Congress

Cataloging-in-Publication Data

Twain, Mark, 1835-1910.

Roughing it / Mark Twain ; illustrated by True Williams, Edward F. Mullen, and others ; editors, Harriet Elinor Smith and Edgar Marquess Branch ; associate editors, Lin Salamo and Robert Pack Browning.

p. cm.-(The Mark Twain library)

"A publication of the Mark Twain

Project of the Bancroft Library."

Includes bibliographical references (p. ). ISBN 978-0-520-26817-3 (pbk. : alk. paper)

1. Twain, Mark, 1835-1910-Journeys-West (U.S.) 2. Authors, American-19th century-Journeys-West (U.S.) 3. West (U.S.)-Description and travel. I. Smith, Harriet Elinor. II. Branch, Edgar Marquess, 1913-. III. Bancroft Library. IV. Title. V. Series: Twain, Mark, 1835-1910. Mark Twain Library.

PS1318.A1 $1996 \quad 818^{\prime} .403$ $95-30007$ [B]

The paper used in this publication meets the minimum requirements of American National Standard for Information Sciences-Permanence of Paper for Printed Library Materials, ANSI/NISO Z39.48-1992 (R 1997) (Permanence of Paper).

The Mark Twain Library is designed by Steve Renick. 
The text of this Mark Twain Library edition of Roughing It

is drawn from the Mark Twain Project's complete edition of The Works and Papers of Mark Twain.

Editorial work for this volume has been supported by a grant to

The Friends of The Bancroft Library from the

\section{J. SKAGGS AND MARY C. SKAGGS FOUNNDATION}

and by matching funds from the NATIONAL ENDOWMENT FOR THE HUMANITIES, an independent federal agency.

Without such generous support, these editions could not have been produced. 
